\title{
POTT'S PARAPLEGIA: A CLASSIFICATION BASED UPON THE LIVING PATHOLOGY ${ }^{1}$
}

\author{
By A. R. Hodgson, O.B.E., F.R.C.S.E., F.A.C.S., and Arthur YAU, F.R.C.S.E. \\ From the Department of Orthopaedic Surgery, University of Hong Kong
}

Historical. There is little doubt that the condition which we call Pott's paraplegia was well recognised before Pott described it in his monograph in I779. Dalechamps (1570), Severinus (I632) and Hall (I779) are some of the authors who drew attention to the condition before Pott. David (I779) described the condition in the same year as Pott. Pott's description is the clearest, fullest and best up to that time. Moreover, he illustrates some of the pathological findings in plates at the end of his monograph. It is proper that his name be associated with the condition, in so many parts of the world today.

The next contribution to the understanding of this condition was in $187 \mathrm{I}$, when Michaud working under the direction and at the suggestion of Charcot, published his findings in a clinical and post-mortem study of cases of Pott's paraplegia. This work is so complete that it is well worth reading today.

In 1925, Sorrel and Sorrel-Dejerine (1925) attempted to classify these paraplegias in relation to the time interval, between the onset of signs and symptoms of Pott's disease and the onset of the signs and symptoms of the paraplegia, and to try to determine the prognosis according to this classification. Early paraplegia was defined as that which had its onset within two years of the onset of the disease, and late paraplegia that which started more than two years after the onset of the disease. Seddon (1935, 1936) and Butler (1935) improved upon this classification, and later Griffiths, Seddon and Roaf (I956) contributed further on this subject.

Purpose. The purpose of this article is to present a classification of Pott's paraplegia which is based upon the living pathology found in these cases at operation over the past I I years in Hong Kong. It is important to note that the operative approaches which have been used have allowed a complete exposure of the spine involved in the disease process.

In addition, we shall try to illustrate the various examples of paraplegia, and although we shall differentiate them for descriptive purposes, it is to be remembered that two or more examples may occur in the same patient.

Classification. For the first part, we have separated paraplegia into two main groups according to the activity of the disease:

Group A. Paraplegia of active disease.

Group B. Paraplegia of healed disease.

While it is usually fairly simple to decide from the patient's clinical condition

${ }^{1}$ Based on a paper delivered at the Annual Meeting of the International Medical Society of Paraplegia in July 1966. Supported by a Research Grant from American International Underwriters Ltd. 
and by routine investigations whether the disease be active or healed, it is a fact that in almost Io per cent. of our cases our preoperative assessment has proved wrong at operation.

\section{Group A. Paraplegia of Active Disease}

This may be subdivided into four groups:

I. Due to external pressure on the spinal cord, by the paravertebral abscess and its contents.

2. Due to the tuberculous infection penetrating the dura, so as to involve the spinal cord in the tuberculous disease, to produce a tuberculous meningo-myelitis.

3. Tuberculosis of the neural arch.

4. Acute thrombosis of arteries supplying the spinal cord. We have not been able to detect this condition at operation. The only report we can find in the literature is that of Seddon (1935, I946). So far we have not seen this in our experimental production of spinal tuberculosis in animals. We presume that this is a rare cause of Pott's paraplegia.

The prognosis of pure pressure paraplegia is remarkably good if the cause of the pressure is removed at operation soon after the onset of symptoms. It is most gratifying to see improvement of the paraplegia, in some cases as soon as the patient recovers from the anaesthetic and in most cases by the first post-operative day. These patients go on to make a complete recovery.

\section{Illustrative Examples of Paraplegia caused by Active Disease}

I. Due to external pressure on the spinal cord by the abscess and its contents.

(a) Pus. In a tuberculous paravertebral abscess, the pus is fluid in the early stage of the disease and caseous in the later stages of the disease. It is easy to see how caseous pus can cause external pressure on the cord (fig. I).

If the pus is fluid it is difficult to determine the pressure within the abscess. We have attempted to measure this and have obtained readings of 15-20 mg. of mercury. We are not satisfied with the accuracy of the method we used. The only other report we have encountered in the literature is that of Lannelogue (I963), who reports a pressure of $18 \mathrm{mg}$. of mercury. It would appear that fluid pus would have enough pressure to cause paraplegia, but it may be 'the last straw which broke the camel's back'.

Pott (I779), Gibney (I897), Menard (I900) and Seddon (I935, I946) all describe lightening of the degree of paraplegia when the abscess becomes clinically recognisable subcutaneously. We have noted the same relief of paraplegia, where the abscess became clinically recognised. This suggests that the rupture of the paravertebral abscess wall by the pus may relieve the pressure on the spinal cord.

(b) Bony Sequestra. These are commonly found in Pott's disease causing pressure upon the spinal cord.

Sequestra arise where vertebral bone becomes deprived of its blood supply and this happens when the coverings of the vertebral body, together with its 


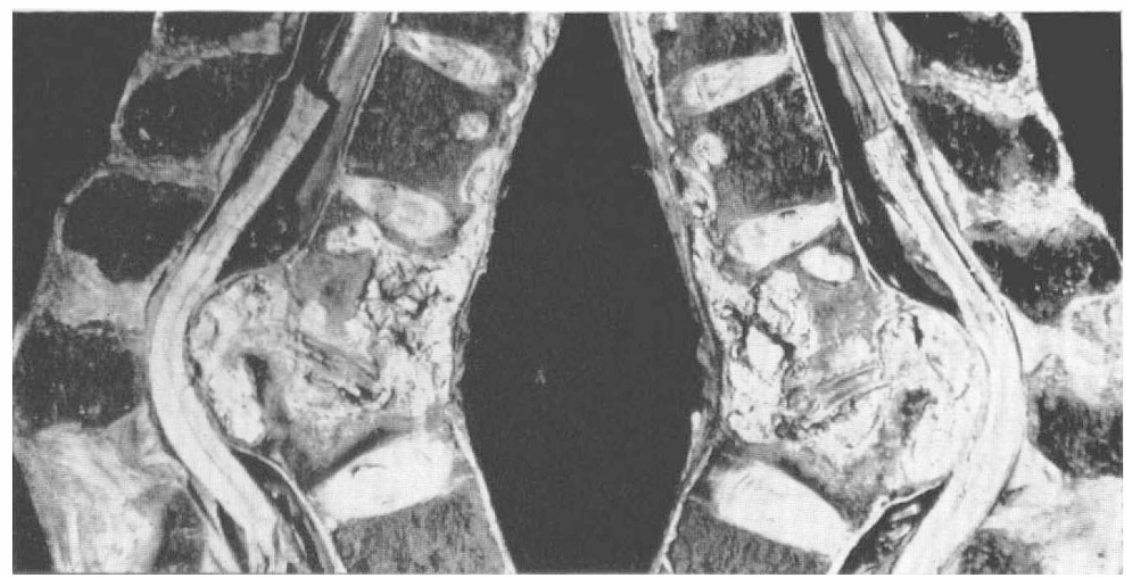

FIG. I

A specimen of a case of Pott's paraplegia, showing pressure upon the spinal cord by caseous pus.

blood supply, are stripped from it by the dissection of the paravertebral abscess as it extends up and down the spine.

These sequestra are squeezed back upon the cord, causing pressure on it; when removed at operation they may leave their imprint on the cord (fig. 2).

(c) Sequestrated Intervertebral Disc. In spinal tuberculosis, the intervertebral disc is usually resistant to the tuberculous infection and our findings support

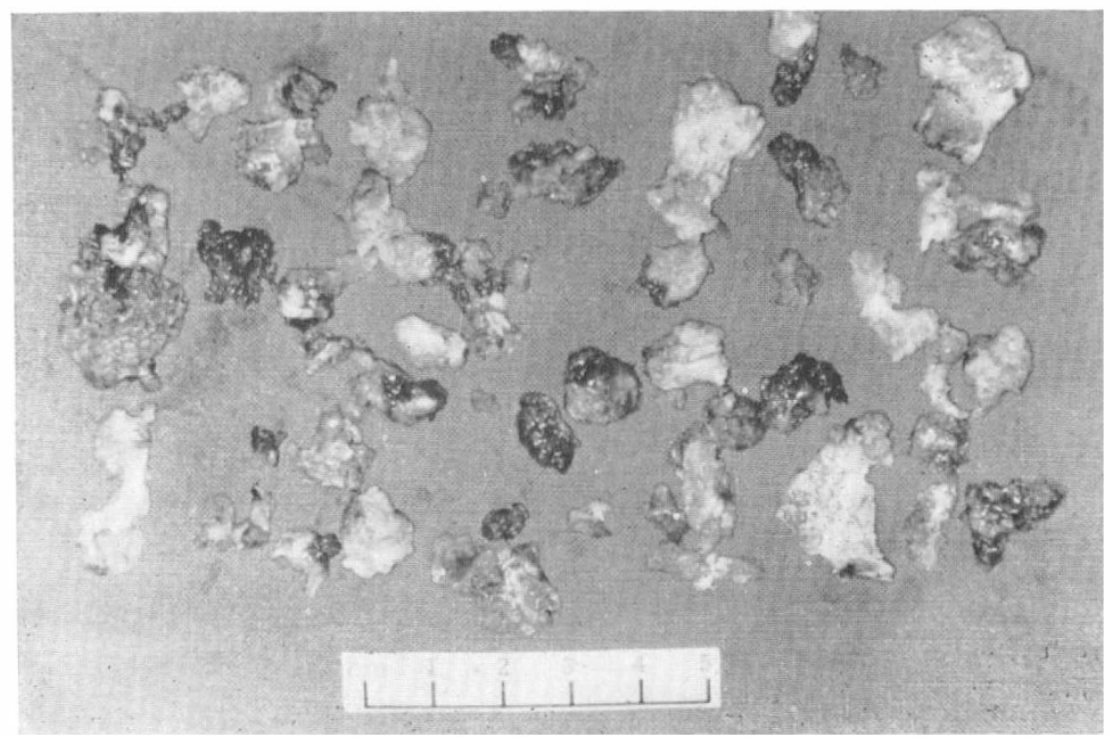

FIG. 2

Showing sequestra and sequestrated disc removed from a Case of Pott's paraplegia at operation. 


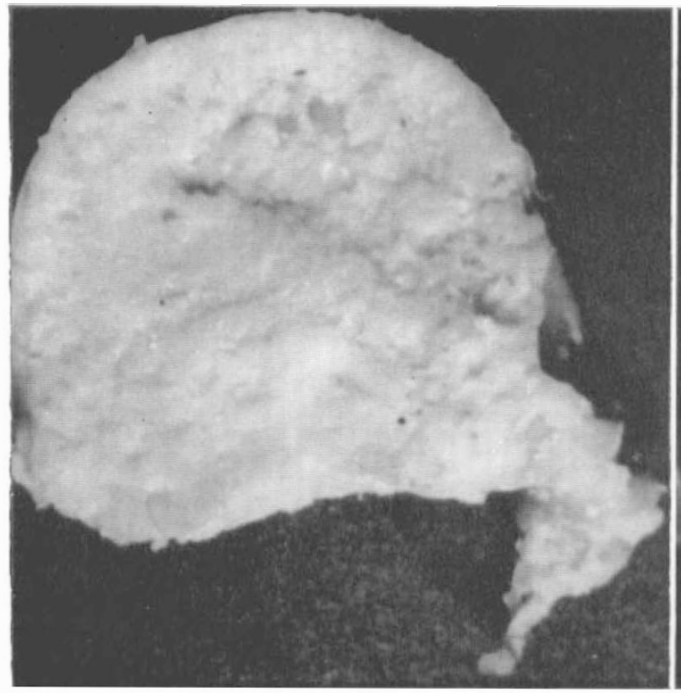

A
FIG. 3

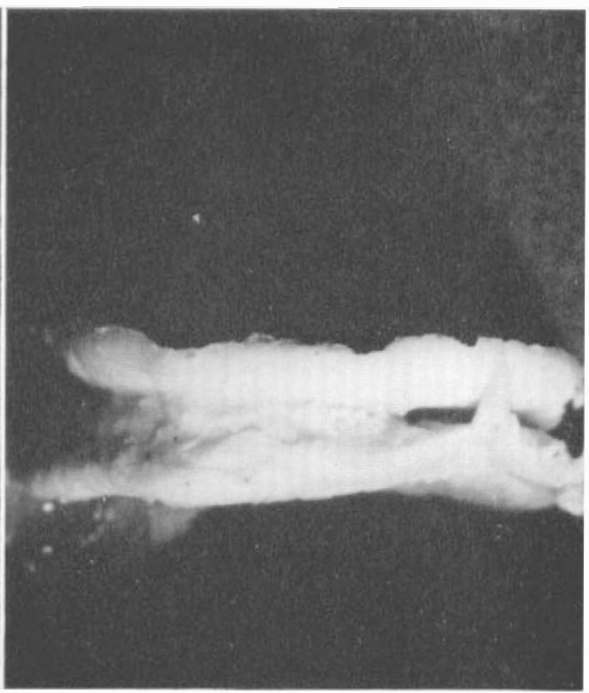

B

Two views of a sequestrated intevertebral disc, removed from an abscess in a case of Pott's paraplegia.

the findings of Compère and Garrison (1936). Hence the intervertebral disc may become sequestrated following destruction of the adjacent portions of the vertebral body on each side of it. It may then be retropulsed and forced backward on to the cord by the forces transmitted from the vertebral bodies above and below: this backward direction is the line of least resistance. It

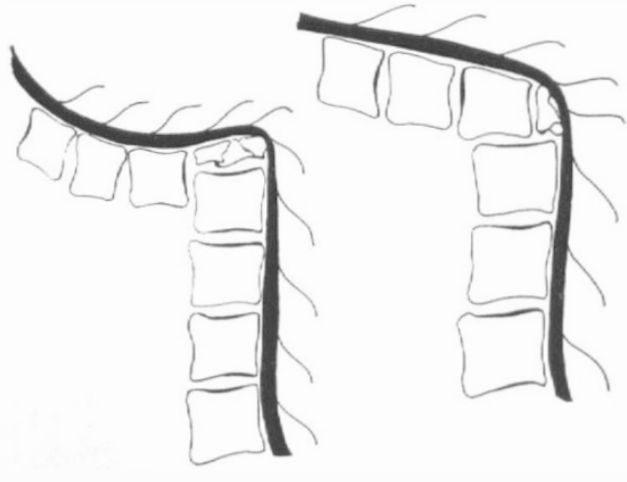

FIG. 4

A, Illustrates the type of subluxation at the cervico-thoracic junction. The inferior cervical vertebra comes to lie in front of the uppermost thoracic vertebra.

B, Shows dislocation of the thoraco-lumbar junction. The anterior surface of the lower thoracic vertebra comes to lie on the upper surface of the uppermost lumbar vertebra. may be seen in Figure I where the sequestrated intervertebral disc may be seen loose in the caseous pus and where the contents of the abscess are retropulsed back on to the crod. Figure 3, A and B show sequestrated intervertebral discs which are almost entire, having been removed from the anterior aspect of the cord in Pott's paraplegia. Occasionally a bony sequestrum and a sequestrated disc are detached together and combine to cause pressure on the dura mater and the cord.

Subluxations and Dislocations. With the destruction of the anterior vertebral column of the spine by the tuberculous disease, the spine starts to subluxate and then dislocate. As Seddon (I946) has pointed out, there is a definite pattern of 

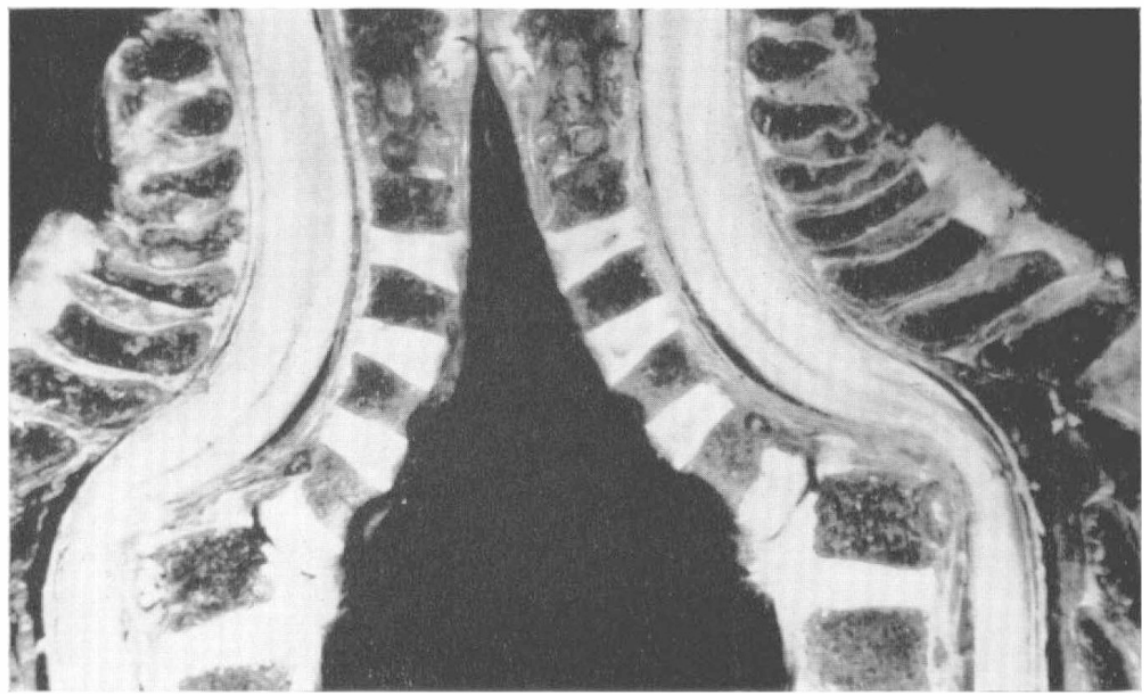

FIG. 5

A specimen to illustrate the deformity at the cervico-dorsal region.

dislocation and the dangerous levels are the cervico-thoracic and thoracolumbar regions (figs. 4 and 5).

Granulation Tissues. Granulation tissue is commonly found in the spinal canal, external to the dura mater and it usually can be easily stripped from it.

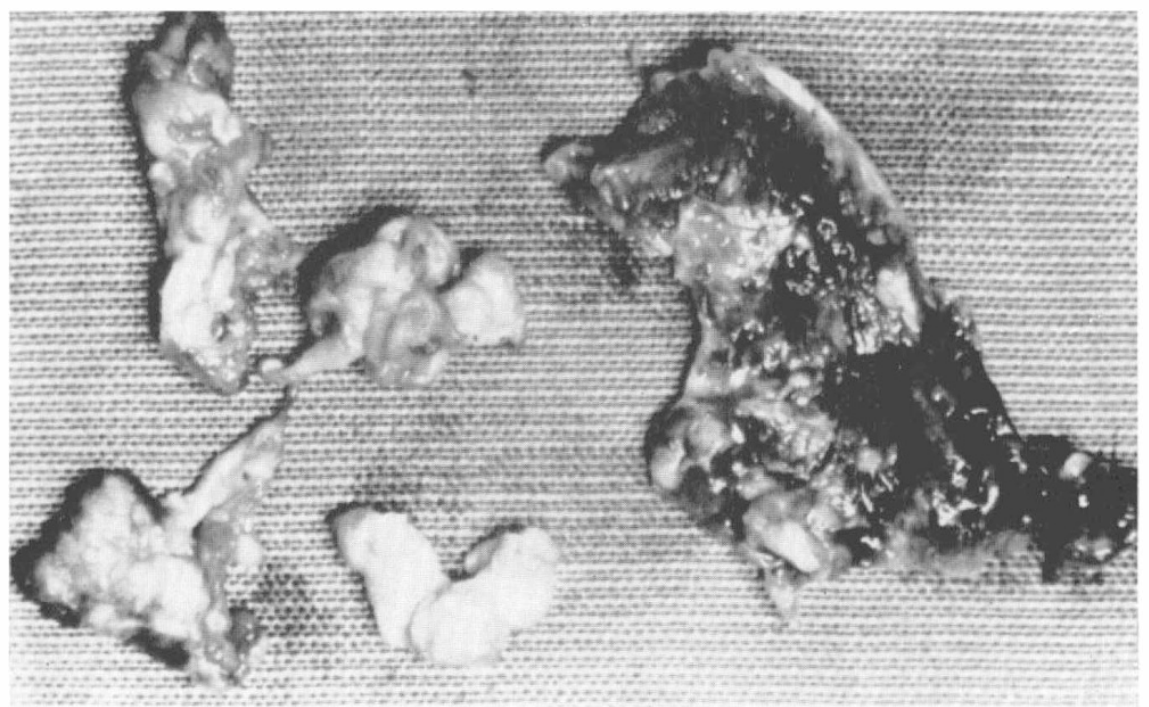

FIG. 6

Shows partly fibrosed tuberculous granulation tissue after removal from the anterior surface of the dura mater. 


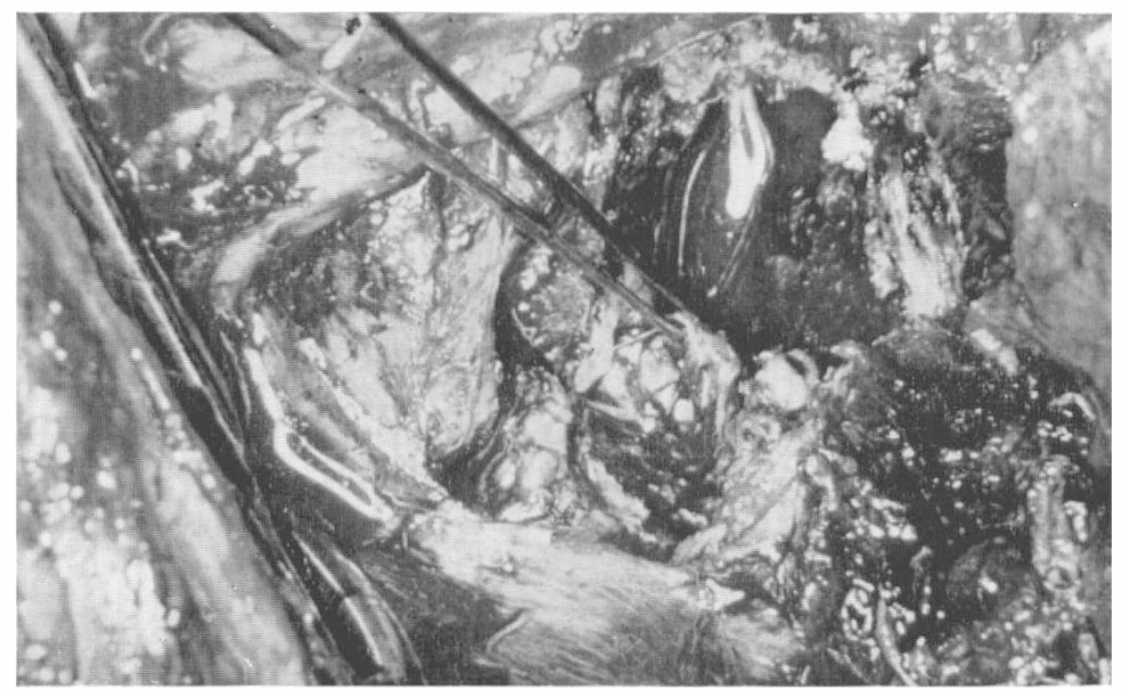

FIG. 7

Photograph taken at operation. The toothed forceps hold and lift the granulation tissue from the dura mater.

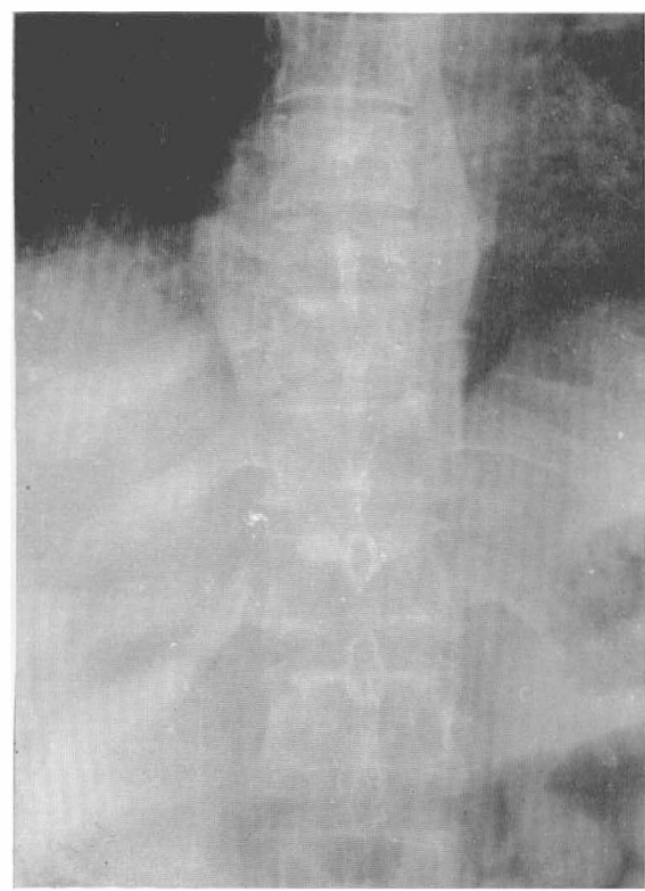

A

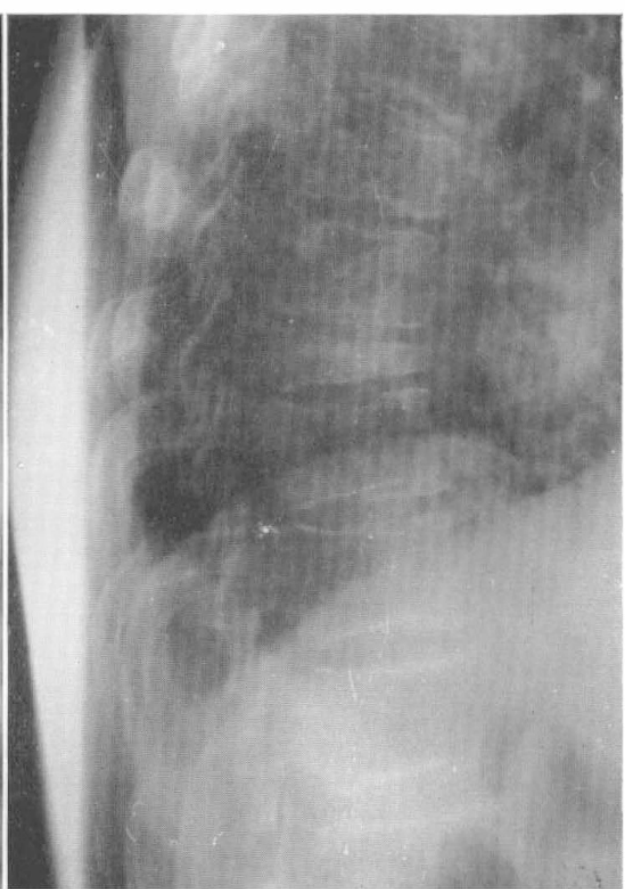

B

FIG. 8

A, A. P. View of a case of tuberculous spine showing the paravertebral abscess and the concertina collapse of the 9 th thoracic vertebra.

B, A lateral view showing concertina collapse of the 9 th thoracic vertebra. 
It consists of sheets of epithelioid cells, round cells, early giant cell formation and early caseation (figs. 6 and 7). What part this plays in the production of pressure paraplegia is difficult to determine, but we feel it is probably only a contributory factor.

Concertina Collapse. This is the name we have given to the vertebral body which has been weakened by extensive tuberculous destruction within itself and then collapses as a concertina, bulging into the spinal cord and producing Pott's paraplegia (fig. 8). I have only seen this condition in the thoracic spine. It was first described by Girdlestone (I93I), who described the collapse of a vertebral body in spinal tuberculosis, which is similar to the collapse of a vertebral body invaded by a tumour.

It should be emphasised that although all these causes of external pressure on the cord have been dealt with separately for clarity of exposition, they often combine to form external pressure on the spinal cord.

2. Penetration of the dura mater and involvement of the cord by the tuberculous disease.

Michaud in I87I was the first author we can discover who drew attention to concomitant infection

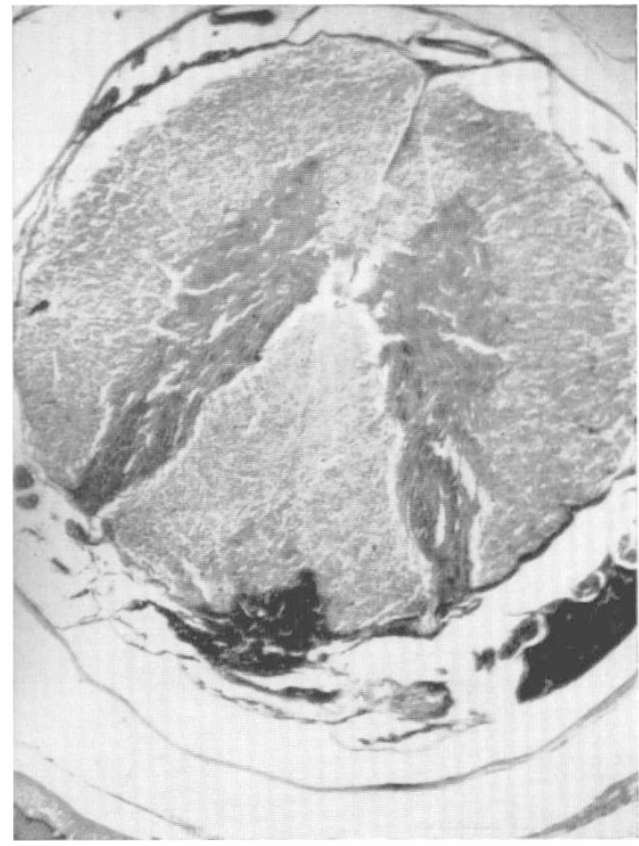

FIG. 9

Transverse section of the spine and spinal cord of a monkey-in which spinal tuberculosis was produced, showing penetration of the dura and involvement of the spinal cord. Note also the tuberculous infection anterior to the vertebral body. of the spinal cord in the presence of Pott's disease. He was followed by many, including Spiller (I898), Rosenheim (1898) and Schmaus (I890). The latter heads his monograph, Die Kompressionsmyelitis, and this term became very common in Germany at that time. This work was either forgotten or in some cases discredited (Griffiths, Seddon \& Roaf, 1956).

It is well to remember that whilst this classification is being subdivided for descriptive purposes, various types of paraplegia may co-exist at the same time.

In Hong Kong we have been able to produce tuberculosis of the spine in animals, some of which have become paraplegic. We have been able to observe, in histological sections of the diseased spine of these animals, the spread of the tuberculous infection across the dura mater and into the spinal cord (fig. 9).

This condition has also been seen at operation, by performing routine biopsies of the dura mater and sectioning the specimen. All grades of penetration of the dura by the tuberculous infection have been found, from complete penetration of the dura to complete freedom from disease. 
Garceau and Brady (1950), in an excellent article, describe their findings in three cases of Pott's paraplegia, in which a careful post-mortem examination had been performed. They emphasised the two main causes of paraplegia as being

(a) mechanical;

(b) inflammatory.

They demonstrate invasion of the dura by the disease and the existence of pachymeningitis and changes within the spinal cord.

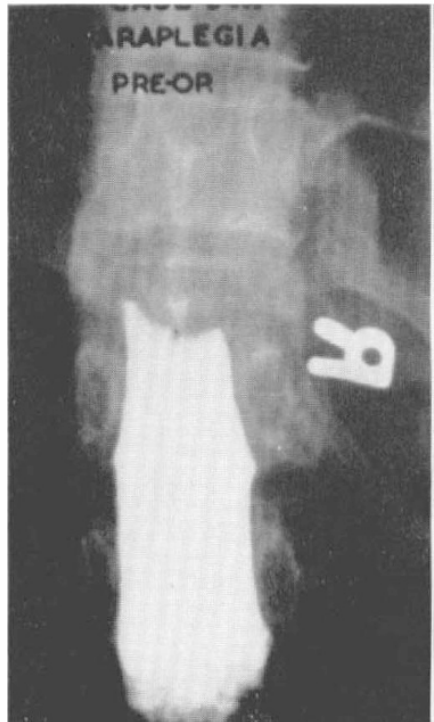

A

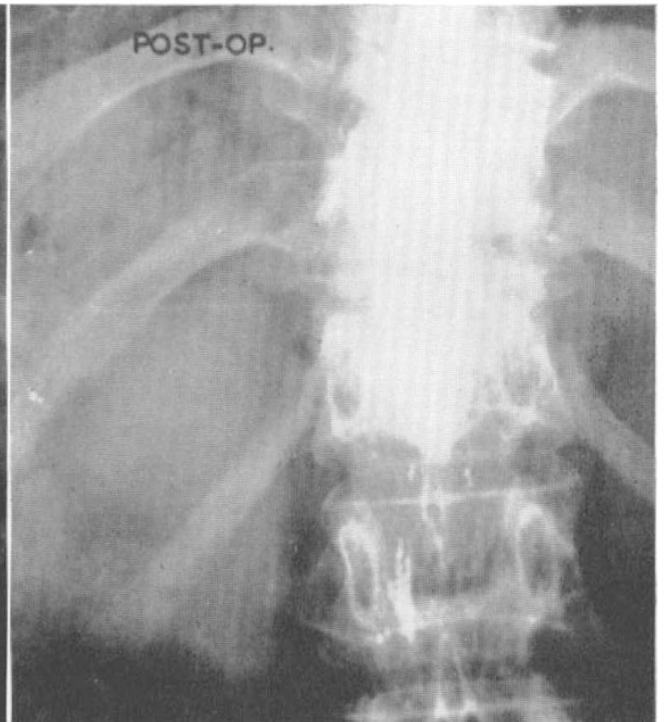

B

FIG. IO

A, Showing complete block of the myelodil pre-operatively.

B, Showing complete freedom post-operatively.

(c) Involvment of the neural arch by tuberculous infection causing paraplegia. This is a rare condition and we have seen only one case in I I years in more than I500 cases of spinal tuberculosis. Schmorl and Junghans (1932) quote Novak, who found eight cases of tuberculosis of the vertebral arches in 2202 cases of vertebral tuberculosis, while Griffiths, Roaf and Seddon (I956) quote three cases in their series of 86 patients of Pott's paraplegia.

The signs in our one case were mainly sensory and cleared up on conservative treatment with recumbency. If decompression had been called for, this would have been a further indication for a laminectomy.

The prognosis of cases of paraplegia, in which the infection involves the cord, is not good and if recovery occurs it is always incomplete and signs of paraplegia persist. 
FIG. II

A. P. Myelography, showing patchy defects in filling, due to meningomyelitis.

FIG. I2

Retropulsion of new bone on to the spinal cord, forming a bony ridge.

A, Shows the healing lesion.

$\mathrm{B}$, Formation of the bony ridge producing pressure on the spinal cord.

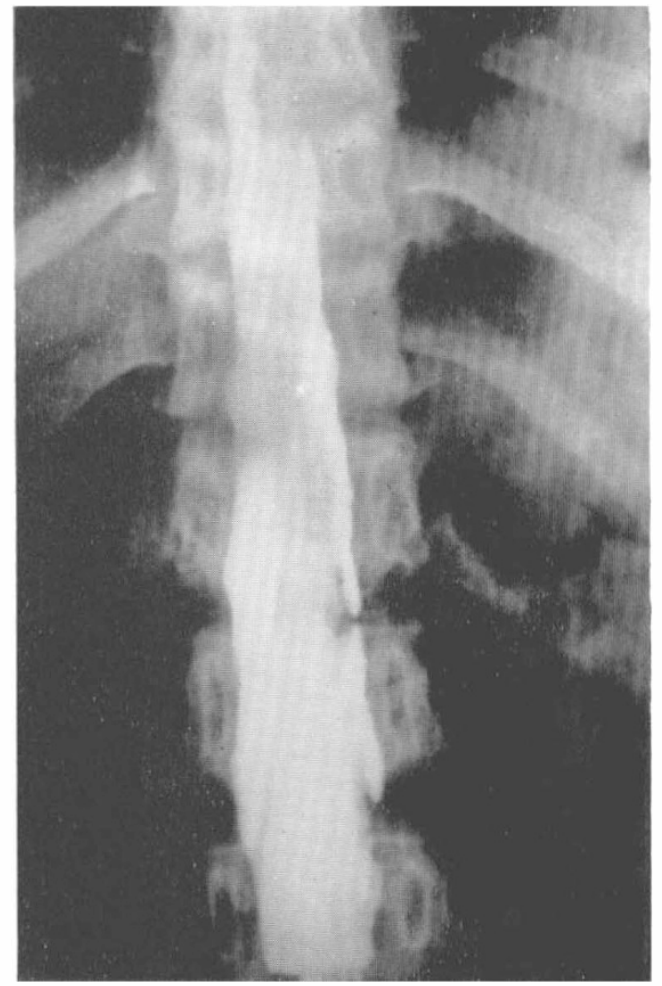

FIG. I I

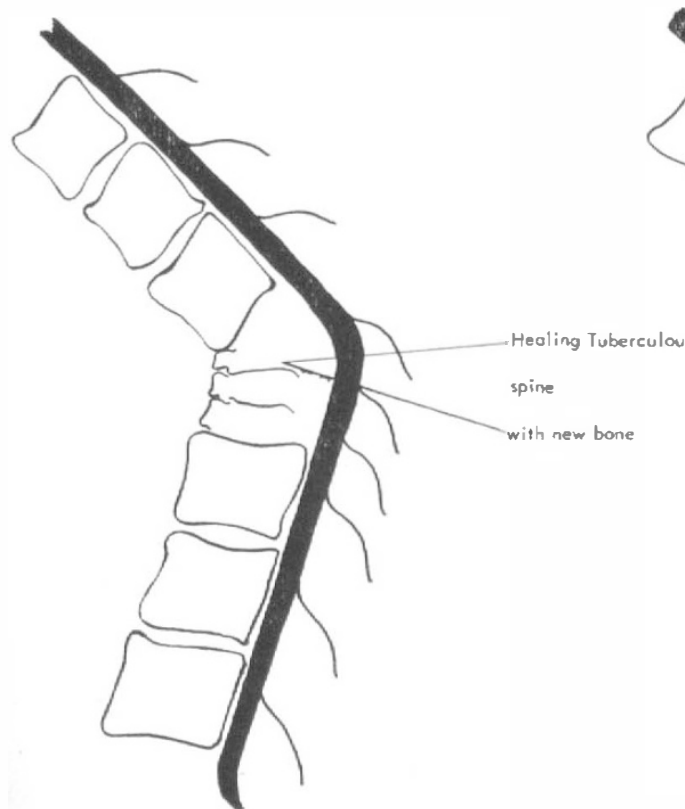

A

FIG. I2

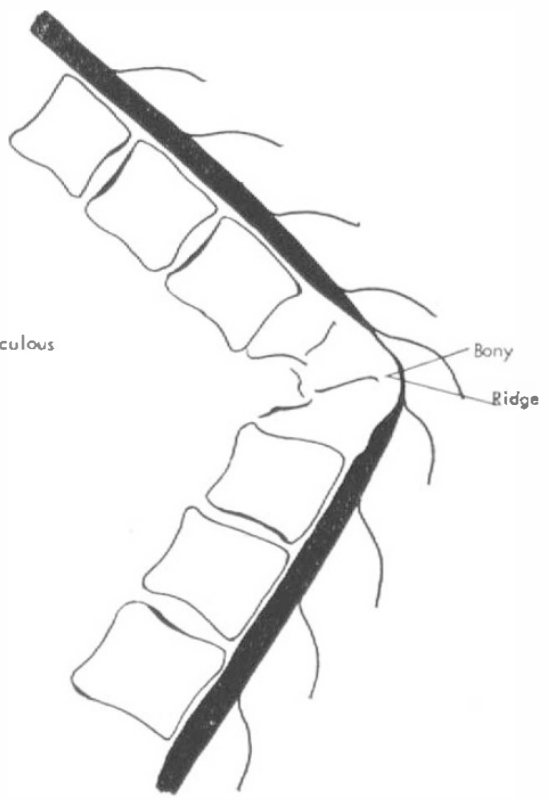

B 
Accordingly, it is essential to try to differentiate between these two types of paraplegia, using clinical signs and investigations whenever possible.

Clinical Differences: As Michaud (I87I) pointed out, where the spinal cord is involved in the infection the paraplegia is much more spastic, withdrawal reflex is common and movement of the toes or foot on one side may cause spasm of the buttock muscles on the other side. Where the paraplegia is due to pressure alone, the spasm is much less marked. It may be increased by assuming the sitting or erect posture and reduced by becoming horizontal again.

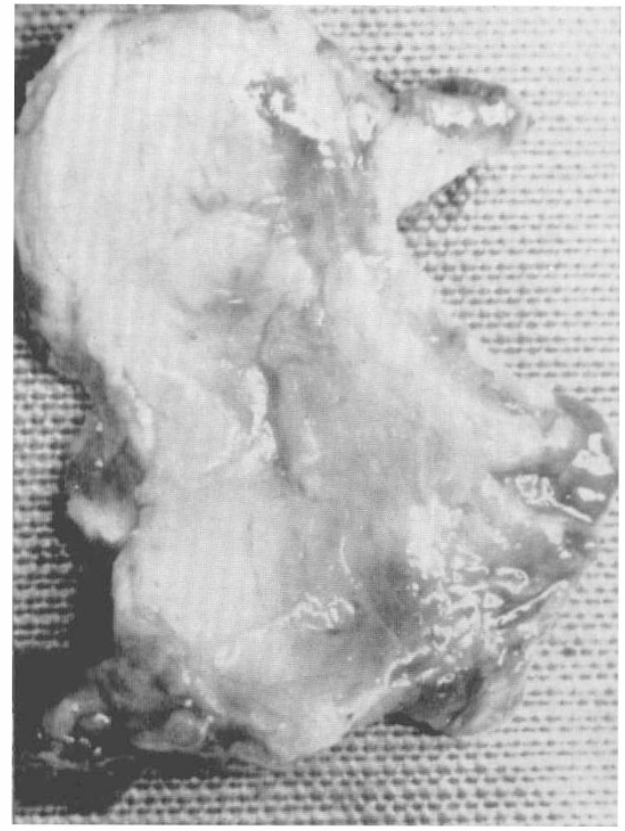

FIG. I3

Shows fibrous tissue which has been removed from the front of the cord.

On investigation, the C.S.F. is usually clear in pressure paraplegia, whilst in paraplegia due to infection of the spinal cord there is usually an increase in cell count, increased sugar level and occasionally culture for the tubercle bacillus is positive.

Myelography is a very useful investigation, as a pressure paraplegia causes a complete block, which is relieved at operation (fig. Io). Involvement of the spinal cord gives rise to patchy defects in filling (fig. I I).

Group B.

\section{Paraplegia of Healed Disease}

I. Transection of the Spinal

Cord by a Bony Bridge. This condition was described by Bouvier (I 858) and also by Griffiths, Seddon and Roaf (1956) and there is no doubt that it does occur, but there is some doubt as to how it occurs. It would appear to us that the following stages may be traced in each case where this type of transection is present.

The First Stage in which there is destruction of vertebral bodies by the tuberculous process. Usually more than two vertebrae are destroyed, to produce a fairly severe kyphosis.

The Second Stage where healing starts and new soft bone forms replacing the diseased area. As this occurs, the kyphosis gradually increases, as the bone is too soft to prevent it. The increasing kyphosis retropulses the new bone across the spinal canal as a bony ridge. This bony ridge then transects the spinal cord (fig. I2).

The Third Stage is when the soft bone becomes normal, hard, cancellous bone, with the average process of maturation. 
2. Pressure on the Cord by Fibrosis of the surrounding Granulation Tissue. In discussing paraplegia of acute disease, we discussed what part the granulation tissue surrounding the spinal cord might play in its production. When this granulation tissue heals, it becomes fibrous tissue which contracts and on contracting can strangulate the spinal cord, causing paraplegia.

If the fibrous tissue (fig. I3) presses upon the posterior portion of the cord, sensory impairment may occur and this is one of the rare indications for laminec-

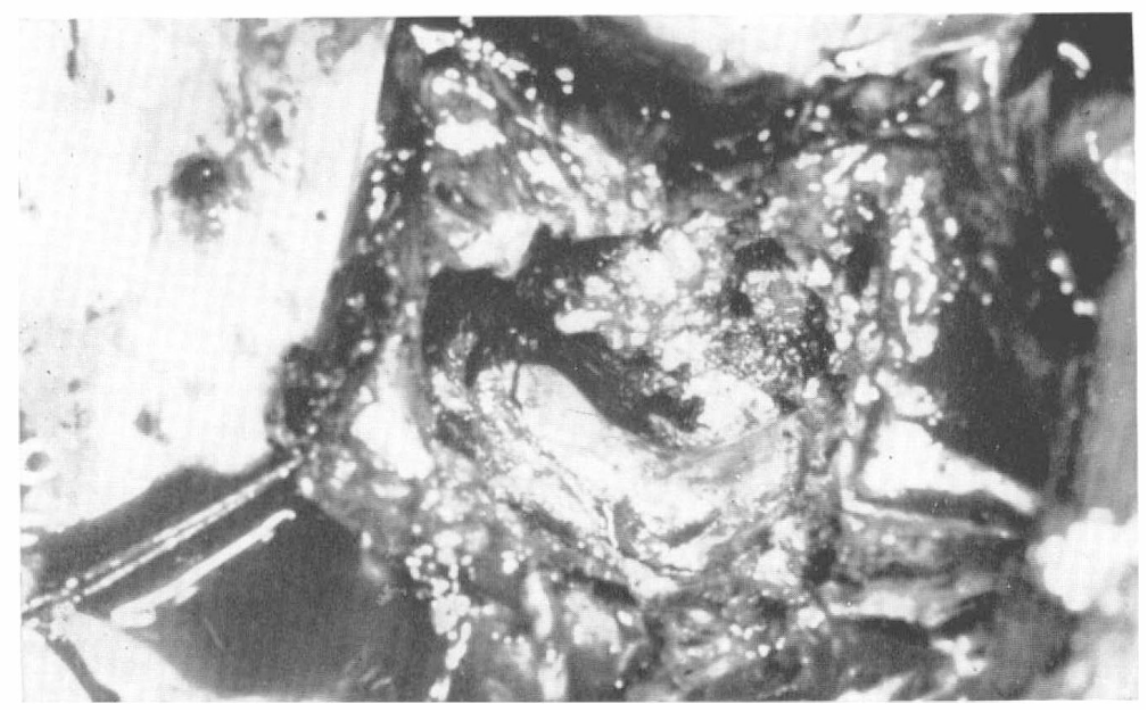

FIG. I4

Shows the dura, after removal of the fibrous plaque illustrated in Figure I3.

tomy in Pott's paraplegia. Even then, it is important to have a stable anterior column before embarking upon the laminectomy.

This condition of fibrosis of the granulation tissue in the healing process and its consequent pressure upon the spinal cord may occur on its own or in combination with the bony ridge described previously. It is of importance to emphasise that where the bony ridge is present, so also is this fibrous tissue. It is not enough to decompress the cord by removal of the bony ridge. We must remove the fibrous tissue as well, to display the dura mater which should pulsate to the impulses of the cerebro-spinal fluid (fig. I4).

The prognosis from paraplegia of healing, even when adequate decompression has been achieved, is not good and recovery usually is incomplete and prolonged.

Other Causes of Paraplegia. (a) Oedema. We agree with Griffiths, Roaf and Seddon that there appears to be little evidence to support this as a cause of paraplegia.

(b) Spinal tumour syndrome. This condition which has been described by Seddon (I946) is rare. We believe it to be due to extradural abscess formation, without involvement of the vertebral bodies, or at least where the involvement of the vertebral bodies goes undetected by present clinical methods of investigation. 


\section{SUMMARY}

A classification of Pott's paraplegia is put forward, based upon our operative findings. Whilst it is often possible to classify the type of paraplegia on clinical grounds, it is only at operation that a definite and certain diagnosis of the cause may be made. An attempt has been made to describe each type of paraplegia for clarity of description, but.in some cases more than one cause of paraplegia may exist at the same time.

Accurate classification of the paraplegia is of vital importance in the prognosis and of great value in the future management of the case.

\section{RÉSUMÉ}

Une classification des paraplégies dûes à la maladie de Pott a été avancée, basée sur notre expérience opératoire. Bien qu'il soit possible souvent de classifier les types de paraplégie sur l'aspect clinique, un diagnostic certain de la cause ne peut être avancé qu'après une opération. On a essayé de décrire chaque type de paraplégie, mais dans certaines atteintes, plus d'une cause peut être responsable de celles-ci.

Une classification bien nette de la paraplégie est d'une importance vitale pour le pronostic et d'une très grande valeur dans le traitement.

\section{ZUSAMMENFASSUNG}

Eine Einteilung der Fälle von Paraplegie als Folge einer Wirbeltuberkulose wird vorgeschlagen, die sich auf Operationsbefunde stützt. Obwohl es oft möglich is, die Typen der Paraplegie klinisch auseinanderzuhalten, lässt sich eine klare und sichere Diagnose der Ursache der Paraplegie nur bei der Operation stellen. Es wird versucht, jeden Typus der Paraplegie eindeutig zu definieren, in einigen Fällen können aber mehrere Ursachen gleichzeitig vorhanden sein. Eine genaue Einteilung der Typen der Paraplegie ist von grösster Wichtigkeit für die Prognosestellung und wertvoll für die postoperative Behandlung jedes Falles.

\section{REFERENCES}

Bouvier, H. (1858). Leçons Cliniques sur les Maladies Chroniques de l'Appareil Locomoteur. Paris.

Butler, R. W. (I935). Br. F. Surg. 22, 738.

Charcot, J. M. (I880). Leçons sur les Maladies du Système Nerveux, Vol. 2, p. 88. Paris. Charcot, J. M. (1883). Gaz. Hôp., Paris, 56, 483.

Charcot, J. M. (1890). Mercredi med., Paris, I, 257.

COMPERE, E. L. \& GARRISON, M. (1936). Ann. Surg. 104, 1038.

Dalechamps, J. (1570). Traité de Chirurgie. Paris.

David, J. B. (I779). Dissertation sur les Effets du Mouvement et de Repos dans les Maladies Chirurgicales. Thèse de Paris.

Garceau, G. J. \& Brady, T. A. (I950). F. Bone ft. Surg. 32A, 89.

GIBNEY, V. P. (I897). F. nerv. ment. Dis. 24, I95.

Girdlestone, G. R. (I93I). Br. F. Surg. 19, I2I.

Griffiths, D., Seddon, H. J. \& Roaf, R. (I956). Pott's Paraplegia. London: Oxford University Press.

Hall, C. (I779). Med. phil. Comment. 6, 7I.

Hippocrates, by AdAMS, F. (1849). The Genuine Works of Hippocrates. London: The Sydenham Society.

Hodgson, A. R. \& Stock, F. E. (I956). Br. F. Surg. 44, 266.

Lannelgue, O. M. (1963). De l'Osteomyelite Aigue, pendant la Croisance. Ann Anbor: University Micro-films Inc. 
Menard, V. (I900). Etude Practique sur le Mal de Pott. Paris.

Michaud, J. A. (I87I). Sur la Meningite de la Myelite dans la Mal Vertebräle. Thèse de Paris.

Potт; P. (I779). Remarks on that kind of palsy of the lower limbs which is frequently found to accompany a curvature of the spine, and is supposed to be caused by it. Together with its method of cure. London.

RosenHeim, S. (1898). Bull. Fohns Hopkins Hosp. 9, 240.

Schmaus, H. (1890). Die Kompressions Myelitis bei Karies der Wirbelsãule. Eine pathologische-histologische und experimentelle Studie. Wiesbaden: J. F. Bergman.

Schmorl, G. \& Junghans, H. (1932). The Human Spine in Health and Disease. London and New York: Grune \& Stratton.

SEDdON, H. J. (I935a). Lancet, 2, 355.

SEDDON, H. J. (1935b). Br. F. Surg. 22, 769.

SEDdon, H. J. (1946). Proc. R. Soc. Med. 39, 723.

SeVerinus, M. A. (1632). De Recondite Abscessuum Natura. Naples.

Sorrel-Dejerine, Y. (I925). Contribution à l'Etude des Paraplegies Pottiques. Paris.

SORREL, E. \& SORREL-Dejerine, Y. (I924). Revue Neurol. 2, 88.

SPILlER, W. G. (1898). Bull. Fohns Hopkins Hosp. 9, I25.

\section{Discussion}

Michaelis (England). I feel it is only right to say that Professor Hodgson is an almost legendary figure in the Far East. There is, so I hear from his chief physiotherapist who was here last year, an entire organisation in China engaged in smuggling their Pott's paraplegias across the frontier into Hong Kong. Many of us, like myself, may have no experience of trans-thoracic surgery, but it is not exactly an easy thing to do. Moreover, these patients are not strong Western Europeans; these are impoverished, miserable, severely ill Chinese refugees. To get such results as Professor Hodgson has achieved, through the quality of doctoring as well as surgery, is quite extraordinary.

The second point I want to make is this: A short time ago, I had occasion to review an extremely interesting paper-a symposium of the first Congress of Rehabilitation in Africa. I think Professor Hodgson was there. In this symposium, there was one statement which surprised me greatly. One of the orthopaedic surgeons there said this: 'We have hardly any beds, we have hundreds of patients waiting for a bed, we must be very careful with admitting patients. If I am offered two cases of paraplegia-one tuberculous and the other traumatic-I will accept the tuberculous one.' That, no one here not knowing enough about the difficult conditions in Africa, can really understand. Is the chance of a traumatic paraplegic to survive and work again in Africa really so bad that a tuberculous paraplegic is preferred to him ? I can think of the reason why this was said. It was probably said because, following Professor Hodgson, they operate at the right time in the right case and in the cases of T.B. paraplegia get more frequently recovery. This is probably the real reason. And still, it sounds odd that the traumatic, healthy individual should have to stay behind when the tuberculous gets his operation. It seems to be particularly doubtful whether this is the right policy when, as Professor Hodgson admitted, some of these people do very well on medical treatment. Would it not be fairer in such circumstances to put them in a medical ward and cure them medically and not rob the traumatic paraplegic of his bed ?

HARRIS (Scotland). I would like to support Dr Michaelis very much in his remarks. I think that medicine owes a great debt to Professor Hodgson and his colleagues on the distinguished work they are doing on Pott's paraplegia. Over the years, surgery and 
medicine have progressed in relation to this terrible disease. Firstly, I suppose the main operation was laminectomy, which is a bad operation, because obviously the disease lies anterior to the cord or roots. Then costo-transversectomy was introduced, which again is a bad operation and unsuccessful, and in more recent years the anterolateral operation. The latter is a good operation in many patients, but it is difficult and time-consuming. I have only had the opportunity, because of the rarity of this condition in this country now, of treating two patients by Professor Hodgson's technique through the chest. Both of these patients-frail, elderly ladies-have done extremely well. The last patient was operated upon two weeks ago, and she had had her illness for some nine months. The remarkable thing to me was that, as Professor Hodgson has mentioned, one can get rapid recovery. Before operation, this patient could only move her toes on one side a little, and she had also severe involvement of sensation and bladder function. We operated-her disease was at the Di I/I 2 level一through the chest on the left side and removed the diseased tissues, as you saw on the slides, and put an iliac graft in. We never send the patients up to the ward until they are round from the anaesthetic. When she came round from the anaesthetic in the anaesthetic room, we asked her what she could do, and she could begin to move her legs. She is now able to lift her legs up and has about grade 4 movement on each side.

Jousse (Canada). Professor Hodgson may be disappointed to know that there is really quite a lot of Pott's disease in the Western world, yet we have also observed, as he recorded, the very amazing recovery of neurological function which follows treatment. I wonder whether he or anyone else has an explanation as to why this is so.

Coeuilliez (Berck-Plage) France. I have been very interested in Professor Hodgson's paper. It was some years ago when he came to Berck and showed us his film about trans-thoracic approach of Pott's disease. He seems to believe that Pott's paraplegia is rare in Europe, but in Berck we have seen about roo Pott's paraplegia since 1950, and 73 of them have been discharged from hospital in the last eight years. I think that, in Europe, our conditions are different from his in Hong Kong. Among our patients, we had nine of healed Pott's paraplegia and in these cases in spite of all kinds of treatment I think they are always severe. We had 5I patients with paraplegia due to Pott's disease and we think they are always the result of chronic tuberculosis and that antibiotic treatment is always alone and by itself sufficient to give as good results as surgery and with less danger. I say with less danger, because the last eight years we saw four cases of paraplegia following operation coming from different places in France, since systematic surgical approach of Pott's disease has become routine practice in everybody's hands. We also saw eight cases of light and incomplete paraplegia which had become complete after operation.

KERR (Scotland). As I spent 23 years in East Africa I think I can understand the problem there pretty well. First of all, Professor Hodgson mentioned the fact that, in some of these cases, the early paraplegia will recover if kept at complete rest horizontally. I have an interesting story about that. Long before there was any question of surgical approach, about 25 years ago, I had a patient for whom I made a plaster shell. Professor Hodgson said they must be kept horizontal. This patient preferred to sit up in his shell and his paraplegia became rapidly worse, until he became encased in his plaster jacket, which prevented him flexing his spine. I also had a case of traumatic paraplegia, upon whom I did-perhaps a lot of people would disapprove-an open reduction and plating in the lumbar region. It was a cauda equina lesion, I had her on rest in bed and the difficulty was that during the night she did not like the discomfort of the bed and she got out and lay under the bed. But, she recovered extremely well.

These are the sort of things you are faced with in tropical conditions: very limited staff, both medical and nursing.

With regard to the question of whether you should treat Pott's paraplegia medically 
or surgically, if you have all the operative facilities to do the job then it is quite the best because it is so much quicker and you get the bed available for another case.

The question of whether in a surgical bed you should have a Pott's paraplegia or a traumatic, that was one remark made by one surgeon in one of approximately roo African countries. I don't think you would get the same remark in other countries, and it all depends on the surgeon's personal attitude. In this country, if you are going through the chest, quite likely you will ask a thoracic surgical colleague to help you. If you are in Africa you must do it yourself and if you are scared about going through the chest you may feel you would rather not do it. There is also the fact that you may be the only surgeon in the district and your particular interest happens to be the stomach. In my own personal experience I took in everything that was presented, whether it was Pott's paraplegia or a traumatic one. I would like to tell two points about the traumatic: The non-cervical lesions did well; the tragedy was how they could look after their skin but we did get this across. There is one thing that I found extremely interesting, namely that the pigmented African skin does not develop pressure sores quite so easily as a white one. This is an impression, it may not be true, but certainly if you have an abdominal fistula you know how the skin gets macerated while the African skin did not get macerated the same way. I found that although we did get pressure ulcers they did not seem to get them as quickly as a European does. So we did get fairly good successes in non-cervical patients.

The question of who was to look after the cervical when there is only a mud and whattle hut for the patient to go to after he has been fully rehabilitated, is a very big problem, and one case I have never understood. The patient was sent to me from up country as a complete cervical C6. I used the patient for teaching purposes, demonstrated this is a complete C6. I am afraid I was not a good enough neurologist to say if there was any sacral sparing but otherwise it was complete. The patient was on traction and calipers and developed very high temperature, and he had pus coming out from his skull wound. This was about 6 weeks after injury. The only thing to do was to take off the traction tongs and I did not think he would survive very long. Yet he made a roo per cent. neurological recovery and walked out of the hospital. I can't explain it.

MCSwEeny (England). I do not think I really need to say anything further to support Professor Hodgson's plea for early surgery. I thought this controversy had ended Io or 12 years ago. Quite apart from leaving the paraplegic to develop the complications of which we are all too well aware, early surgery returns his spincter control, usually within two or three days. In other words, there is little plea today for conservative management of Pott's paraplegia. The second point I would like to raise almost as a question is this: In this country at the moment we are more familiar with the second type of Pott's disease, not the florrid abscess, where we find an antero-lateral decompression a lesser operation and in fact the more satisfactory, bearing in mind the stability of the spine.

Grogono (Canada). As Dr Jousse has said, we still get tuberculosis in Canada, mainly amongst the Indians and Eskimos, and we have had a small series of anterior procedure, which we were able to do thanks to Dr. Hodgson's film, which have been very satisfactory. I would just like to ask him how long he is prepared to treat the patient conservatively before he proceeds surgically, particularly say in a young child of 5 who is developing paraplegia. This particular child had a very large paravertebral abscess and a small lesion in the lung as well, and we were anxious to improve his general condition before treating the paraplegia surgically. We noticed that the paraplegia did completely resolve itself by conservative treatment before we removed the abscess. He was at first spastic after the operation but in the course of a week or ten days complete recovery occurred. I wonder how he tackles the problem in children, what he does initially and how he follows them up. 
Professor Hodgson (Hong Kong). I will try to integrate some of this discussion, and I am delighted with the very excellent points brought up. I think Mr. Kerr made a very good point-it depends on your facilities. You can treat it in both ways and some people get far better results with conservative and others with operative. The only danger with conservative treatment is that you get a pure pressure paraplegia going on to cord disease-we have seen this-and when you have cord disease you have got irreversible paraplegia, and as you saw we had some cases of that.

Now, we will operate on a paraplegia next day. We think it vital that you get at him as soon as possible, then you get higher results. I hope in ro years' time to come back to you here to give the latest Ioo cases and I would expect a 90 per cent. rate.

Now, the question of Africa; I do not know the answer but I would think the surgeon in Africa felt he had a little more control surgically over a Pott's paraplegia than over a traumatic-that is, he probably could relieve the paraplegia in Pott's disease whereas he might not be able to relieve a traumatic paraplegia. That is one of the reasons why he went for his Pott's paraplegia. The other reason is that I understand the rehabilitation services in Africa are not as sophisticated as they are in the Western world and it is more difficult to treat paraplegics.

With regard to the question of Dr. Grogono, children have a magnificent capacity for recovery, and I hate to say this but I believe that children's spinal cord can recover. I have had cases who were completely paraplegic for four years and made a complete recovery at the end of that time. Children are very much more likely to make a complete recovery than adults. I would still treat a child with surgery simply because I know that within six weeks that child will be out of hospital and probably back home and pretty certainly cured.

I do not know how to explain the rapid recovery. But it is fascinating how quickly they can recover. It suggests, perhaps, that this is a vascular thing although one wonders how a blood vessel can recover its circulation so quickly. The interesting thing is that the countries where surgery is being practised on a large scale are those countries which have great numbers of tuberculosis of the spine-Poland, the Philippines. These sort of places where they have sophisticated set-ups for hospitals and surgery are treating them surgically for the main reason that they can get through the hospital quicker as I understand it. I know that colleagues in Berck-Plage have gone back to conservative treatment, and in Sico we are going to have a little round-table discussion on this. The Medical Research Council is supporting a research project which is world-wide to try to compare the relative merits of conservative and operative treatment. I think I can sum up by saying there are many roads to Rome, and so far as I am concerned in Hong Kong in my hands the highest percentage of cures in the shortest possible time come with surgery. 